\title{
PENERAPAN TOTAL QUALITY MANAGEMENT (TQM) DALAM MENINGKATKAN MUTU PELAYANAN PADA PT. PEGADAIAN CABANG SOPPENG
}

\author{
Nuinaya ${ }^{1}$.Gusniar ${ }^{2}$. Abdul Muttalib ${ }^{3}$ \\ Program Studi Manajemen Fakultas Ekonomi dan Bisnis \\ Universitas Muhammadiyah Makassar \\ (gusniar@gmail.com)
}

\section{ABSTRAK}

Tujuan penelitian ini adalah untuk mengetahui penerapan Total Quality Management dalam meningkatkan mutu pelayanan nasabah pada PT. Pegadaian Cabang Soppeng. Penelitian ini menggunakan 100 responden. Yang menjadi responden adalah nasabah PT Pegadaian Cabang Soppeng. Sedangkan pengambilan sampel yang digunakan adalah teknik sampling jenuh atau sensus. Metode pengumpulan data yang digunakan teknik kuesioner. Uji analisis yang digunakan yaitu uji regresi linear sederhana. Berdasarkan hasil

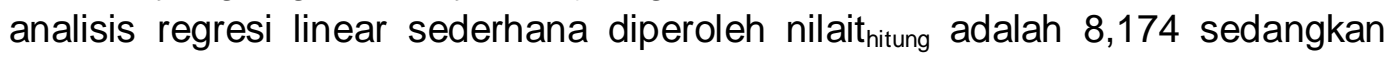
nilait $_{\text {table }}$ sebesar 1,98397 . Hal ini membuktikan bahwa nilait ${ }_{\text {hitung }}$ lebih besar dari padat $_{\text {tabel. }}$ Dengan demikian Ha diterima. Interpretasi menunjukkan bahwa Penerapan Total Quality Management berpengaruh positif dalam hal meningkatkan mutu pelayanan nasabah pada PT. Pegadaian Cabang Soppeng. Karena dengan adanya Total Quality Management yang tinggi akan memperbaiki kinerja dalam mengelola perusahaan agar dapat meningkatkan penghasilan perusahaan.

Kata Kunci : Total Quality Management dan Mutu Pelayanan

\section{PENDAHULUAN}

\section{Latar belakang}

Total Quality Management merupakan suatu sistem yang dapat dikembangkan menjadi pendekatan dalam usaha untuk memaksimumkan daya saing organisasi melalui perbaikan terus menerus atas produksi, jasa, tenaga kerja, dan proses. Sistem akuntansi manajemen yang digunakan dalam penelitian ini meliputi sistem pengukuran kinerja. Pengukuran kinerja karyawan dapat meningkatkan kualitas. Dari sudut pembelajaran frekuensi pelaporan pengukuran kinerja produksi akan membantu karyawan mengembangkan efektivitas pekerjaan strategis dengan cepat dan dapat meningkatkan kinerjanya. Peningkatan produktivitas kinerja karyawan ini tentu saja akan sangat bermanfaat bagi perusahaan. 
Jurnal Profitability Fakultas Ekonomi Dan Bisnis

Volume 1 No 2 Tahun 2017

Penerapan Total Quality Management memerlukan perubahan mendasar infrastruktur organisasional, meliputi sistem alokasi wewenang, pembuatan keputusan, system pengukuran kinerja, system reward dan hukuman. Implementasi teknik Total Quality Management harus diikuti dengan menerapkan system penghargaan dalam bagian pekerjaan yang meningkatkan kualitas sehingga dapat berguna sebagai sarana pengembangan karir serta meningkatkan efektivitas pekerjaan strategis dengan cepat dan dapat meningkatkan kinerja manager dan karyawan. PT.Pegadaian Cabang Soppeng adalah sebuah BUMN di Indonesia yang usaha intinya adalah bidang jasa penyaluran kredit kepada masyarakat atas dasar hukum gadai.

PT. Pegadaian Cabang Soppeng dituntut untuk tetap menjaga eksistensinya atau kelangsungan hidup perusahaan dengan terus meningkatkan kinerja manajerial perusahaan, untuk mencapai misi tersebut PT. Pegadaian Cabang Soppeng menerapkan manajemen mutu terpadu. Dalam manajemen mutu terpadu semua usaha manajemen diarahkan pada suatu tujuan yaitu terciptanya kepuasan konsumen. Dengan perkataan lain fokus perusahaan adalah pelanggan PT. Pegadaian Cabang Soppeng telah menerapkan sistem mutu yang memenuhi SNI ISO 9001:2008 (Quality Management SistemRequirements) per tanggal 20 januari 2011.

Mempertahankan hasil produksi baik jasa maupun barang yang berkualitas dan bermutu, dengan mempunyai pengawasan terhadap produk yang telah ditetapkan untuk mempertahankan Total Quality Manajemen. Hal inilah penulis tertarik melakukan penelitian pada perusahaan PT. Pegadaian Cabang Soppeng.Untuk memperoleh pengakuan dari konsumen (pelanggan) telah ditentukan produk berkualitas untuk mengkompensasikan manajemenmanajemen yang dikeluarkan untuk memproduksi barang dan jasa sesuai dengan bidang perusahaan.

PT. Pegadaian pada Kantor Cabang Soppeng penting untuk mempertahankan kualitas produk (quality manajemen) dengan menggunakan pengawasan dalam pelayanan nasabah yang efisien dan efektif. Keadaan ini merupakan suatu hal yang wajar, karena perusahaan adalah organisasi yang usahanya bertujuan untuk mencapai kemakmuran. Perusahaan harus berusaha agar tetap memenuhi fungsinya dalam menunjang perkembangan dan kesuksesan menghadapi persaingan dengan perusahaan yang sejenis. 
Jurnal Profitability Fakultas Ekonomi Dan Bisnis

Volume 1 No 2 Tahun 2017

Mencapai hal tersebut perlu adanya pengendalian kualitas, sehigga tetap diterima oleh konsumen.

Sehubungan usaha tersebut, maka perhatian utama perusahaan pada umumnya dititik beratkan pada peranan pelayanan dalam proses produk jasa dalam hubungan dengan pengendalian mutu (qualitymanajement) hasil produk yang dihasilkan, karena pengawasan dalam pelayanan yang dikeluarkan relevan dengan hasil produksinya. Pengawasan ataupun mutu pelayanan pada setiap nasabah harus diketahui untuk menentukan prosedur yang telah ditetapkan perusahaan. Pimpinan perusahaan seharusnya mengawasi karyawan yang harus diberikan pelayanan yang terbaik dan dapat juga diketahui bahwa tiap-tiap transaksi perusahaan selalu membandingkan dengan penyelesaian kegiatan lainnya yang disertai dengan pengawasan pada saat berproduksi.

Agarseorang pengusaha lebih mudah untuk mengetahui tingkat keterampilan bagi seorang karyawan, dengan menampilan pelayanan kepada nasabah, sebab mutu pelayanan dapat dinilai bagi karyawan jika nasabah bisa bertambah dengan metode kecepatan, ramah, tepat, cepat dan ulet sehingga nasabah betah pada perusahaan. Ini merupakan salah satu masalah yang penting dan cukup ruwet untuk dipecahkan.

Untuk mencapai tingkat kepuasan konsumen tidak hanya dipengaruhi oleh satu faktor saja melainkan beberapa faktor yang turut menentukan kecepatan dan ramah, total quality manajemen memang perlu dijaga untuk mempertahankan nasabah yang telah ada dan bagaimana cara menarik nasabah baru yang akan menjadi nasabah tetap, pimpinan memainkan peran pentingnya terhadap bawahan mengenai mutu pelayanan dengan memberikan sesuatu yang terbaik kepada seseorang. Berdasarkan uraian tersebut penulis memilih perusahaan PT. Pegadaian Cabang Soppeng sebagai obyek penelitian dengan mengangkat judul "Penerapan Total Quality Manajement Dalam Meningkatkan Mutu Pelayanan Pada PT. Pegadaian Cabang Soppeng", mengingat dewasa ini perusahaan menjadi instansi yang berhubungan langsung dengan masyarakat

\section{METODE PENELITIAN}

Untuk memperoleh data yang dibutuhkan, maka penulis memilih Perusahaan Pegadaian Cabang Soppeng. Waktu penelitian yang dibutuhkan kurang lebih dua bulan yaitu dimulai dari bulan Februari sampai April 2017. Populasi ialah sejumlah penduduk atau individu yang palingsedikit mempunyai 
suatu sifat yang sama. Jadi populasi adalah jumlah keseluruhan dan unit analisa yang ciri-cirinya akan diduga(Hadi, 2015). Adapun jumlah populasi pada PT. Pegadaian Kantor Cabang Soppeng tahun 2017 adalah 100 nasabah.

Menurut Husein (2011) Sampel adalah bagian kecil dari suatu populasi. Sedangkan menurut Tiro (2013: 3) Sampel adalah jumlah anggota yang dipilih atau diambil dari suatu populasi. Sedangkan pengambilan sampel yang digunakan sehingga dapat merepresentasikan karakteristik populasi adalah menggunakan teknik sampling jenuh atau sensus. Jadi dalam penelitian ini semua populasi penelitian digunakan sebagai sampel penelitian. Hal ini dilakukan karena populasi relatif kecil atau penelitian yang ingin membuat generalisasi dengan kesalahan yang sangat kecil. Maka sampel dari penelitian ini ada 100 nasabah.

Jenis Data dan Sumber Data

Data kuantitatif, yaitu data yang diperoleh melalui perusahaan dalam bentuk angka-angka.

a. Data primer adalah data yang diperoleh atau dikumpulkan oleh peneliti secara langsung dari sumber data utama. Data primer disebut juga sebagai data asli atau data baru yang memiliki sifat up to date. Untuk mendapatkan data primer, peneliti harus mengumpulkannya secara langsung. Teknik yang digunakan peneliti untuk mengumpulkan data primer adalah penyebaran kuesioner. Model skala yang digunakan adalah Skala Likert.

b. Data Sekunder adalah data yang diperoleh atau dikumpulkan oleh peneliti dari berbagai sumber yang telah ada (peneliti sebagai tangan kedua). Data sekunder dapat diperoleh dari berbagai sumber seperti Biro Pusat Statistik (BPS), buku, laporan, jurnal, dan lain-lain.

\section{Metode Pengumpulan Data}

Untuk mengumpulkan data serta keterangan yang diperlukan dalam penyusunan proposal ini, maka digunakan metode penelitian studi kasus (Case study method) dan pengumpulan data melalui penelitian, sebagai berikut :

1. Penelitian pustaka (library research), yaitu mengadakan penelitian yang dilakukan secara langsung terhadap beberapa buku sebagai bahan pustaka, serta karangan ilmiah yang erat kaitannya dengan masalah yang di atas. 
Jurnal Profitability Fakultas Ekonomi Dan Bisnis

Volume 1 No 2 Tahun 2017

2. Penelitian lapangan (field reserch), yaitu penelitian yang dilakukan dengan jalan mengadakan kunjungan secara langsung kepada obyek penelitian yang telah ditetapkan.

Untuk mengumpulkan data lapang yang diperlukan, digunakan teknik/ metode, sebagai berikut :

1. Observasi, yaitu mengadakan pengamatan secara langsung terhadap obyek penelitian dengan jalan membuat suatu konsep mengenai masalah yang berhubungn judul penelitian penulis.

2. Wawancara, yaitu tanya jawab yang dilakukan dengan pimpinan perusahaan dan beberapa staf yang langsung menangani masalah pelayanan kepada nasabah.

\section{Metode Analisis}

Berdasarkan hipotesis yang diajukan maka metode analisis data yang digunakan adalah:

1. Analisis deskriptif, yaitu menjelaskan peranan total quality management terhadap peningkatan tingkat mutu pelayanan.

2. Metode Analisis regresi sederhana.

Analisis regresi linier sederhana adalah hubungan secara linear antara satu variabel independen $(X)$ dengan variabel dependen $(Y)$. Analisis ini untuk mengetahui arah hubungan antara variabel independen dengan variabel dependen apakah mempunyai pengaruh terhadap peningkatan mutu pelayanan terhadap perum pegadaian cabang soppeng.Rumus regresi linear sederhana sebagi berikut:

$$
\mathrm{Y}=\mathrm{a}+\mathrm{bX}+e
$$

Dimana:

$$
\begin{aligned}
& \mathrm{Y}=\text { Kepuasan atau mutu pelayanan } \\
& \mathrm{X}=\mathrm{TQM} \text { (Total Quality Management) } \\
& \mathrm{a}=\text { Konstanta } \\
& e=\text { error } \\
& \mathrm{b}=\text { Koefisien regresi }
\end{aligned}
$$

\section{Pengujian Hipotesis}

Untuk pengujian hipotesis dirumuskan sebagai berikut:

$\mathrm{H}_{0}: \beta_{1} \leq 0$ lawan $\mathrm{H}_{1}: \beta_{1}>0$ dimana:

$\mathrm{H}_{0}$ : tidak ada pengaruh Total Quality Management terhadap Mutu Pelayanan 
Jurnal Profitability Fakultas Ekonomi Dan Bisnis

Volume 1 No 2 Tahun 2017

$\mathrm{H}_{1}$ : Total Quality Management berpengaruh positif terhadap Mutu Pelayanan

\section{Definisi Operasional}

Dalam Penyusunan skripsi ini penulis membuat beberapa definisi operasional variabel mengenai atribut total quality manajemen dan kepuasan/mutu pelayanan.Variabel yang digunakan terdiri dari dua variabel, yang pertama adalah total quality managementsebagai variable bebas (Independent Variable), sedangkan yang kedua adalah kepuasan/mutu pelayanan sebagai variabel terikat (Dependent Variable). Adapun definisi operasional/konsep yang dikemukakan dalam total quality management, sebagai berikut :

1. Perencanaan secara garis besar diartikan seagai proses mendefinisikan tujuan organisasi, membuat strategi untuk mencapai tujuan itu, dan mengembangkann rencana aktivitas kerja organisasi. Pada dasarnya yang dimaksud perencanaan yaitu memberi jawaban atas pertanyaan-pertanyaan apa (what), siapa (who), kapan (when), dimana (where), mengapa (why), dan bagaimana (how). Jadi perencanaan yaitu fungsi seorang manajer yang berhubungan dengan pemilihan dari sekumpulan kegiatan-kegiatan dan pemutusan tujuan-tujuan, kebijaksanaan-kebijaksanaan serta programprogram yang dilakukan. Perencanaan merupakan proses terpenting dari semua fungsi manajemen karena tanpa perencanaan berjalan.

2. Integritas (Integrity), Integritas berarti Kejujuran, Moral, Nilai, Keadilan, dan Kepatuhan terhadap Fakta dan Ketulusan. Integrity merupakan Karakteristik dari apa yang pelanggan (internal atau eksternal) harapkan dan layak diterima.

3. Kepercayaan (Trust), Kepercayaan adalah produk dari Integritas dan perilaku Etis. Tanpa Kepercayaan, kerangka TQM tidak bisa dibangun. Kepercayaan mendorong partisipasi penuh dari semua anggota. Hal ini memungkinkan adanya Kebanggaan dan Komitmen.

4. Diklat, sangat penting dalam peningkatan Produktivitas dan Kinerja. Anda sebagai Supervisor bertanggung jawab dalam Implementasi TQM di wilayah kerja dan mengajarkan filosofi TQM.

5. Kerjasama Tim, juga merupakan elemen kunci dari TQM untuk menjadi sukses dalam bisnis. Tim akan mendapatkan solusi lebih cepat dan lebih 
Jurnal Profitability Fakultas Ekonomi Dan Bisnis

Volume 1 No 2 Tahun 2017

baik untuk setiap permasalahan. Tim juga memberikan perbaikan yang lebih Permanen dalam Proses dan Operasional. Dalam tim, orang merasa lebih nyaman menceritakan masalah yang mungkin terjadi, dan bisa mendapatkan bantuan dari orang lain untuk menemukan solusi yang tepat.

6. Kepemimpinan (Leaderships), mungkin elemen paling penting dalam TQM. Kepemimpinan dalam TQM membutuhkan manajer untuk memberikan Visi yang Inspiratif, membuat arahan Strategis yang mudah dipahami dan menanamkan nilai-nilai sebagai panduan bagi bawahan. Seorang supervisor harus Paham TQM, Percaya dan menunjukkan Keyakinan dan Komitmennya melalui praktek sehari-hari. Supervisor memastikan bahwa Strategi, Filosofi, Nilai-nilai dan Tujuan mengalir turun di seluruh organisasi untuk memberikan Fokus, Kejelasan dan Arah. TQM harus diperkenalkan dan dipimpin oleh manajemen puncak. Komitmen dan Keterlibatan pribadi dari manajemen puncak diperlukan dalam menciptakan dan menyebarkan nilai kualitas yang jelas, tujuan yang konsisten dan dalam menciptakan dan menggunakan Sistem yang terdefinisi baik, Metode dan Ukuran Kinerja untuk mencapai tujuan.

7. Kredibilitas adalah tingkat kepecayaan sebuah perusahaan di mata klien , pelanggan, mitra bisnis, dan sumber daya keuangan . kredibilitas merupakan kombinasi dari reputasi dan profil kredit perusahaan. Jika kurang satu atau yang lain maka perusahaan dapat dicap memiliki kredibilitas yang buruk.

8. Pengendalian atau dalam bahasa Inggris disebut dengan Controlling merupakan salah satu fungsi penting manajemen yang harus dilakukan oleh semua manajer untuk mencapai tujuan organisasinya. Pengendalian dapat diartikan sebagai fungsi manajemen untuk memastikan bahwa kegiatan dalam organisasi dilakukan sesuai dengan yang direncanakan. Fungsi Pengendalian atau controlling ini juga memastikan sumber-sumber daya organisasi telah digunakan secara efisien dan efektif untuk mencapai tujuan organisasinya.

Adapun definisi operasional/konsep yang dikemukakan dalam mutu pelayanan, sebagai berikut :

1. Kualitas Produk adalah kemampuan suatu produk untuk melaksanakan fungsinya meliputi, daya tahan keandalan, ketepatan kemudahan operasi dan perbaikan, serta atribut bernilai lainnya. 
Jurnal Profitability Fakultas Ekonomi Dan Bisnis

Volume 1 No 2 Tahun 2017

2. Harga adalah suatu nilai tukar yang bisa disamakan dengan uang atau barang lain untuk manfaat yang diperoleh dari suatu barang atau jasa bagi seseorang atau kelompok pada waktu tertentu dan tempat tertentu. Istilah harga digunakan untuk memberikan nilai finansial pada suatu produk barang atau jasa.pelanggan akan merasa puas bila hasil mereka menunjukkan bahwa produk yang mereka gunakan berkualitas

3. Service Quality (SQ) adalah ketidaksesuaian antara harapan (E) sebuah layanan dengan kinerja $(P) S Q=P-E$. Service Quality $(S Q)$ merupakan salah satu konsep layanan perusahaan yang bisa diandalkan untuk bertahan di tengah persaingan yang semakin ketat. pelanggan akan merasa puas bila mereka mendapatkan pelayanan yang baik atau sesuai dengan yang diharapkan.

4. Faktor Emosional merupakan salah satu faktor yang mempengaruhi kepuasan konsumen terhadap suatu produk. Pelanggan akan merasa bangga dan mendapatkan keyakinan bahwa orang lain akan kagum terhadap dia bila menggunakan produk dengan merek tertentu yang cenderung mempunyai tingkat kepuasan yang lebih tinggi.

5. Kemudahan artinya mudah. Dalam pegadaian kemudahan dapat diartikan mudah dalam bertransaksi, persyaratannya ringan dan mudah, prosedurnya sederhana serta pelayanannya cepat.

6. Ketepatan adalah sesuai dengan tujuan yang akan dicapai atau sesuai dengan perencanaan. Dalam hal ini tepat sasaran sesuai dengan harapan pihak perusahaan.

\section{HASIL PENELITIAN DAN PEMBAHASAN}

\section{Karakteristik Responden}

Penelitian di lapangan dilakukan dengan cara membagikan angket yang telah disediakan oleh peneliti langsung kepada responden yang berhasil ditemui. Angket disebarkan kepada para nasabah yang ada di PT. Pegadaian Cabang Soppeng. Dalam penelitian ini diambil sebanyak 100 nasabah sebagai sampel penelitian. Karakteristik responden yaitu menguraikan deskripsi identitas responden menurut sampel penelitian yang telah ditetapkan. Salah satu tujuan dengan deskripsi karakteristik responden adalah memberikan gambaran yang menjadi sampel dalam penelitian ini. Dalam penelitian ini, karakteristik responden 
Jurnal Profitability Fakultas Ekonomi Dan Bisnis

Volume 1 No 2 Tahun 2017

dikelompokkan menurut umur dan jenis kelamin. Oleh karena itu uraian mengenai karakteristik responden dapat diuraikan sebagai berikut:

\section{Karakteristik responden berdasarkan umur}

Adapun karakteristik responden berdasarkan umur dapat dilihat melalui tabel 5.1 berikut:

Tabel 5.1 Karakteristik Responden Berdasarkan Umur

\begin{tabular}{|c|c|c|}
\hline \multirow{2}{*}{ Umur } & \multicolumn{2}{|c|}{ Tanggapan Responden } \\
\cline { 2 - 3 } & $\mathrm{F}$ & $\%$ \\
\hline $\mathbf{2 1 - 3 0}$ tahun & 31 & 31 \\
\hline $\mathbf{3 1 - 4 0}$ tahun & 48 & 48 \\
\hline $\mathbf{4 1 - 5 0}$ tahun & 11 & 11 \\
\hline >50 tahun & 10 & 10 \\
\hline Jumlah & 100 & 100 \\
\hline
\end{tabular}

Sumber : Data diolah dari kuesioner, 2017

Berdasarkan hasil olah data mengenai karakteristik responden berdasarkan umur, maka jumlah responden terbesar adalah responden yang berumur 31-40 tahun yakni 48,0\%. Sehingga dapat dikatakan bahwa rata-rata nasabah PT. Pegadaian Cabang Soppeng berumur 31-40 tahun.

1. Karakteristik responden berdasarkan jenis kelamin

Adapun karakteristik responden berdasarkan jenis kelamin dapat dilihat melalui tabel 5.2 berikut:

Tabel 5.2 Karakteristik Responden Berdasarkan Jenis Kelamin

\begin{tabular}{|c|c|c|}
\hline \multirow{2}{*}{ Jenis Kelamin } & \multicolumn{2}{|c|}{ Tanggapan Responden } \\
\cline { 2 - 3 } & $\mathrm{F}$ & $\%$ \\
\hline Perempuan & 64 & 64,0 \\
\hline Laki-laki & 36 & 36,0 \\
\hline Jumlah & 100 & 100,0 \\
\hline
\end{tabular}

Sumber : Data diolah dari kuesioner, 2017

Berdasarkan hasil olah data mengenai karakteristik responden berdasarkan jenis kelamin, maka jumlah responden terbesar adalah responden yang berjenis kelamin perempuan sebanyak $64,0 \%$. Sehingga dapat dikatakan bahwa rata-rata nasabah PT. Pegadaian Cabang Soppeng berjenis kelamin perempuan. 
Jurnal Profitability Fakultas Ekonomi Dan Bisnis

Volume 1 No 2 Tahun 2017

\section{Deskripsi Data Atas Variabel Penelitian}

\section{Variabel Total Quality Management (X)}

Variabel Total Quality Managementdiukur menggunakan kuesioner yang terdiri dari 24 item pertanyaan dengan indikator perencanaan, integritas, kepercayaan, diklat, kerjasama, kepemimpinan, kredibilitas dan pengendalian. Berdasarkan hasil olah data penjabaran responden atas item yang digunakan untuk mengukur variabel Total Quality Management, dapat ditunjukkan pada tabel 5.3 dan tabel 5.4 berikut ini:

Tabel 5.3 Distribusi Variabel Total Quality Management

\begin{tabular}{|c|c|c|c|c|c|}
\hline $\begin{array}{l}\mathbf{N} \\
\mathbf{0}\end{array}$ & Pernyataan & SS & $\mathbf{S}$ & TS & STS \\
\hline & Perencanaan & & & & \\
\hline 1 & $\begin{array}{l}\text { Merencanakan segala sesuatu kegiatan- } \\
\text { kegiatan yang akan dilakukan demi mencapai } \\
\text { tujuan. }\end{array}$ & 70 & 24 & 6 & - \\
\hline 2 & $\begin{array}{l}\text { Pelaksanakan kegiatan operasional perusahaan } \\
\text { menyusun program kerja yang terinci }\end{array}$ & 61 & 25 & 14 & - \\
\hline \multirow[t]{2}{*}{3} & $\begin{array}{l}\text { Penyusun program kerja menjadikan kegiatan } \\
\text { kerja perusahaan lebih terarah }\end{array}$ & 55 & 39 & 6 & - \\
\hline & Integritas & & & & \\
\hline 4 & $\begin{array}{l}\text { Taat pada peraturan-peraturan baikdiawasi } \\
\text { maupun tidak diawasi. }\end{array}$ & 42 & 38 & 20 & - \\
\hline 5 & $\begin{array}{l}\text { Tiap bidang melaporkan hasil kerjanya kepada } \\
\text { pimpinan sesuai dengan waktu yang ditetapkan }\end{array}$ & 41 & 52 & 7 & - \\
\hline \multirow[t]{2}{*}{6} & $\begin{array}{l}\text { Kesadaran karyawan perusahaan dalam hal } \\
\text { kehadiran }\end{array}$ & 25 & 35 & 40 & - \\
\hline & Kepercayaan & & & & \\
\hline 7 & Percaya terhadap hasil kerja karyawan Iain. & 48 & 45 & 7 & - \\
\hline 8 & $\begin{array}{l}\text { Kepribadian karyawan dalam proses } \\
\text { pelaksanaan tugas }\end{array}$ & 57 & 32 & 11 & - \\
\hline \multirow[t]{2}{*}{9} & $\begin{array}{l}\text { Karyawan dilibatkan dalam proses pengabilan } \\
\text { keputusan }\end{array}$ & 55 & 38 & 7 & - \\
\hline & Diklat & & & & \\
\hline $\begin{array}{l}1 \\
0\end{array}$ & $\begin{array}{l}\text { Tingkat prestasi kerja meningkat setelah } \\
\text { mengikuti pelatihan }\end{array}$ & 38 & 31 & 31 & - \\
\hline $\begin{array}{l}1 \\
1\end{array}$ & $\begin{array}{l}\text { Keahlian personal sesuai dengan pekerjaan } \\
\text { masing-masing }\end{array}$ & 56 & 39 & 5 & - \\
\hline \multirow[t]{2}{*}{$\begin{array}{l}1 \\
2\end{array}$} & $\begin{array}{l}\text { Peningkatan loyalitas dan komitmen karyawan } \\
\text { terhadap pekerjaan setelah mengikuti pelatihan }\end{array}$ & 45 & 36 & 19 & - \\
\hline & Kerjasama & & & & \\
\hline $\begin{array}{l}1 \\
3\end{array}$ & $\begin{array}{l}\text { Kerjasama tim dalam organisasi sangat penting } \\
\text { dalam menyelesaikan permasalahan. }\end{array}$ & 48 & 42 & 10 & - \\
\hline $\begin{array}{l}1 \\
4\end{array}$ & $\begin{array}{l}\text { Mengadakan pertemuan kelompok untuk } \\
\text { menyelesaikan permasalahan }\end{array}$ & 31 & 32 & 37 & - \\
\hline $\begin{array}{l}1 \\
5\end{array}$ & $\begin{array}{l}\text { Kesediaan para karyawan perusahaan untuk } \\
\text { bekerja sama dalam pelaksanaan pekerjaan }\end{array}$ & 43 & 49 & 8 & - \\
\hline
\end{tabular}


Jurnal Profitability Fakultas Ekonomi Dan Bisnis

Volume 1 No 2 Tahun 2017

\begin{tabular}{|c|c|c|c|c|c|}
\hline & Kepemimpinan & & & & \\
\hline $\begin{array}{l}1 \\
6\end{array}$ & $\begin{array}{l}\text { Mampu menginspirasi karyawan yang lain dan } \\
\text { membuat arah strategi yang dapat dipahami } \\
\text { oleh semua komponen. }\end{array}$ & 39 & 41 & 20 & - \\
\hline $\begin{array}{l}1 \\
7\end{array}$ & $\begin{array}{l}\text { Pimpinanmemberikanbataswaktuyangharusdipe } \\
\text { nuhiolehkaryawanpadasaatmelakukanpelaksana } \\
\text { antugasdanpelaporan kegiatan }\end{array}$ & 66 & 28 & 8 & - \\
\hline \multirow[t]{2}{*}{$\begin{array}{l}1 \\
8\end{array}$} & $\begin{array}{l}\text { Pekerjaankaryawanselaludipantauolehpimpinan } \\
\text { agarmenghasilkan pekerjaan bermutu. }\end{array}$ & 47 & 31 & 22 & - \\
\hline & Kredibilitas & & & & \\
\hline $\begin{array}{l}1 \\
9\end{array}$ & $\begin{array}{l}\text { Kepercayaan dari perusahaan lain untuk } \\
\text { melakukan kerjasama meningkat }\end{array}$ & 51 & 41 & 8 & - \\
\hline $\begin{array}{l}2 \\
0\end{array}$ & $\begin{array}{l}\text { Kepercayaan masyarakat kepada perusahaan } \\
\text { meningkat }\end{array}$ & 40 & 41 & 19 & - \\
\hline \multirow{2}{*}{$\begin{array}{l}2 \\
1\end{array}$} & Banyak pihak yang ingin melakukan kerjasama & 29 & 64 & 7 & - \\
\hline & Pengendalian & & & & \\
\hline $\begin{array}{l}2 \\
2\end{array}$ & $\begin{array}{l}\text { Mengontrol segala kegiatan yang dilakukan } \\
\text { pegawai atau karyawan demi tercapainya tujuan. }\end{array}$ & 14 & 40 & 46 & - \\
\hline $\begin{array}{l}2 \\
3\end{array}$ & $\begin{array}{l}\text { Pimpinanmemberiarahanyangjelaskepadakarya } \\
\text { wandalammelaksankan tugas. }\end{array}$ & 47 & 44 & 9 & - \\
\hline $\begin{array}{l}2 \\
4\end{array}$ & $\begin{array}{l}\text { Pimpinanmendorongbawahanuntukmenjadiahlidi } \\
\text { bidangmasing-masing }\end{array}$ & 59 & 34 & 7 & - \\
\hline
\end{tabular}

Sumber : Data diolah dari kuesioner, 2017

Berdasarkan tabel 5.3 diatas dapat dijelaskan bahwa deskipsi variabel Total Quality Management dari masing-masing indikator terdapat 3 pernyataan. Untuk item pernyataan tentang perencanaan, integritas, kepercayaan, diklat, kerjasama, kepemimpinan, kredibilitas, dan pengendalian menunjukkan bahwa dari 100 responden didapatkanpaling banyak yang menjawab sangat setuju (SS) ada pada indikator perencanaan yaitu 70 responden. Sedangkan paling sedikit ada pada indikator pengendalian yaitu 14 responden. Untuk jawaban setuju diperoleh paling banyak yang menjawab setuju (S) terdapat pada indikator kredibilitas yaitu 64 responden sedangkan paling sedikit terdapat pada indikator perencanaan yaitu 24 responden.

Pada jawaban tidak setuju diperoleh paling banyak yang menjawab tidak setuju (TS) terdapat pada indikator pengendalian yaitu 46 responden sedangkan paling sedikit ada pada indikator diklat yaitu 5 responden. Pada jawaban sangat tidak setuju (STS) semua indikator tidak terdapat satupun responden yang menjawab sangat tidak setuju. 
Jurnal Profitability Fakultas Ekonomi Dan Bisnis

Volume 1 No 2 Tahun 2017

Tabel 5.4 Persentase Distribusi Variabel Total Quality Management

\begin{tabular}{|c|c|c|c|c|c|c|c|c|c|c|c|}
\hline \multirow[t]{3}{*}{ Indikator } & \multicolumn{8}{|c|}{ Alternatif Jawaban Responden } & \multirow{2}{*}{\multicolumn{2}{|c|}{ Jumlah }} & \multirow{3}{*}{$\begin{array}{l}\text { Mean } \\
\text { item }\end{array}$} \\
\hline & \multicolumn{2}{|c|}{ STS } & \multicolumn{2}{|c|}{ TS } & \multicolumn{2}{|c|}{$\mathrm{S}$} & \multicolumn{2}{|c|}{ SS } & & & \\
\hline & $f$ & $\%$ & $\mathrm{~F}$ & $\%$ & $F$ & $\%$ & $f$ & $\%$ & $F$ & $\%$ & \\
\hline $\begin{array}{l}\text { Perencanaa } \\
\text { n }\end{array}$ & 0 & 0 & 37 & 12,33 & 89 & $\begin{array}{c}29,6 \\
7\end{array}$ & 174 & $\begin{array}{r}58, \\
00\end{array}$ & 300 & 100 & 3,46 \\
\hline Integritas & 0 & 0 & 67 & 22,33 & 125 & $\begin{array}{c}41,6 \\
7\end{array}$ & 108 & $\begin{array}{r}36, \\
00\end{array}$ & 300 & 100 & 3,14 \\
\hline $\begin{array}{l}\text { Kepercayaa } \\
\text { n }\end{array}$ & 0 & 0 & 25 & 8,33 & 115 & $\begin{array}{c}38,3 \\
3\end{array}$ & 160 & $\begin{array}{r}53 \\
33\end{array}$ & 300 & 100 & 3,45 \\
\hline Diklat & 0 & 0 & 55 & 18,33 & 106 & $\begin{array}{c}35,3 \\
3\end{array}$ & 139 & $\begin{array}{r}46, \\
33\end{array}$ & 300 & 100 & 3,28 \\
\hline Kerjasama & 0 & 0 & 55 & 18,33 & 123 & $\begin{array}{c}41,0 \\
0\end{array}$ & 122 & $\begin{array}{r}40, \\
67\end{array}$ & 300 & 100 & 3,22 \\
\hline $\begin{array}{l}\text { Kepemimpi } \\
\text { nan }\end{array}$ & 0 & 0 & 48 & 16,00 & 100 & $\begin{array}{c}33,3 \\
3\end{array}$ & 152 & $\begin{array}{r}50, \\
67\end{array}$ & 300 & 100 & 3,35 \\
\hline Kredibilitas & 0 & 0 & 34 & 11,33 & 146 & $\begin{array}{c}48,6 \\
7\end{array}$ & 120 & $\begin{array}{r}40, \\
00\end{array}$ & 300 & 100 & 3,29 \\
\hline $\begin{array}{l}\text { Pengendali } \\
\text { an }\end{array}$ & 0 & 0 & 62 & 20,67 & 118 & $\begin{array}{c}39,3 \\
3\end{array}$ & 120 & $\begin{array}{r}40, \\
00\end{array}$ & 300 & 100 & 3,19 \\
\hline
\end{tabular}

Sumber : Data diolah dari kuesioner, 2017

Berdasarkan tabel 5.4 diatas dapat dijelaskan bahwa deskipsi variabel Total Quality Management dari masing-masing indikator terdapat 3 pernyataan. Untuk item pernyataan tentang perencanaan menunjukkan bahwa dari 100 responden didapatkan $0(0 \%)$ jawaban sangat tidak setuju, jawaban tidak setuju sebanyak 37 (12,33\%), jawaban setuju sebanyak 89 (29,67\%), dan jawaban sangat setuju sebanyak $174(58,00 \%)$. Nilai rata untuk item pernyataan perencanaan adalah 3,46 . Hal ini menggambarkan bahwa perencanaan yang baik dalam sebuah perusahaan akan membuat perusahaan menjadi meningkat. Indikator kedua yang diukur adalah integritas karyawan menunjukkan bahwa jawaban sangat tidak setuju sebanyak $0(0,0 \%)$, jawaban tidak setuju sebanyak 67 (22,33\%), jawaban setuju sebanyak 125(41,67\%), dan jawaban sangat setuju sebanyak 108 (36,00\%). Nilai rata-rata untuk item pernyataan integritas adalah 3,14 . Hal ini menggambarkan bahwa sebagian besar karyawan taat pada peraturan-peraturan baikdiawasi maupun tidak diawasi.

Indikator ketiga yang diukur adalah kepercayaan antar karyawan menunjukkan bahwa jawaban sangat tidak setuju sebanyak 0 responden $(0,0 \%)$, jawaban tidak setuju sebanyak 25 (8,33\%), jawaban setuju sebanyak 115 $(38,33 \%)$, dan jawaban sangat setuju sebanyak 160 (53,33\%). Nilai rata-rata untuk item penyataan kepercayaan adalah 3,45. Hal ini menggambarkan bahwa 
Jurnal Profitability Fakultas Ekonomi Dan Bisnis

Volume 1 No 2 Tahun 2017

sebagian besar karyawan percaya terhadap hasil kerja karyawan lain. Indikator keempat yang diukur adalah diklat menunjukkan bahwa jawaban sangat tidak setuju sebanyak $0(0,0 \%)$, jawaban tidak setuju sebanyak 55 (18,33\%), jawaban setuju sebanyak 106 (35,33\%), dan jawaban sangat setuju sebanyak 139 $(46,33 \%)$. Nilai rata-rata untuk item pernyataan diklat adalah 3,28. Hal ini menggambarkan bahwa sebagian besar karyawan mengatakan keahlian personal harus sesuai dengan pekerjaan masing-masing.

Indikator kelima yang diukur adalah kerjasama antar karyawan menunjukkan bahwa jawaban sangat tidak setuju sebanyak $0(0,0 \%)$, jawaban tidak setuju sebanyak 55 (18,33\%), jawaban setuju sebanyak $123(41,00 \%)$, dan jawaban sangat setuju sebanyak 122 (40,67\%). Nilai rata-rata untuk item pernyataan kerjasama adalah 3,22. Hal ini menggambarkan bahwa sebagian besar karyawan mengatakan kerjasama tim dalam organisasi sangat penting dalam menyelesaikan permasalahan. Indikator keenam yang diukur adalah kepemimpinan menunjukkan bahwa jawaban sangat tidak setuju sebanyak 0 $(0,0 \%)$, jawaban tidak setuju sebanyak $48(16,00 \%)$, jawaban setuju sebanyak $100(33,33 \%)$, dan jawaban sangat setuju sebanyak $152(50,67 \%)$. Nilai rata-rata untuk item pernyataan kepemimpinan adalah 3,35. Hal ini menggambarkan bahwa sebagian besar karyawan tidak membutuhkan kepemimpinan oleh karyawan lain sehingga karyawan kurang mampu menginspirasi karyawan yang lain dan membuat arah strategi yang dapat dipahami oleh semua komponen.

Indikator ketujuh yang diukur adalah kredibilitas menunjukkan bahwa jawaban sangat tidak setuju sebanyak $0(0,0 \%)$, jawaban tidak setuju sebanyak 34 (11,33\%), jawab setuju sebanyak 146 (48,6\%), dan jawaban sangat setuju sebanyak 120 (40,00\%). Nilai rata-rata untuk item pernyataan akredibilitas adalah 3,29. Hal ini menggambarkan bahwa sebagian besar karyawan sangat setuju untuk pemberian penghargaan bagi karyawan yang berprestasi. Indikator kedelapan yang diukur adalah pengendalian menunjukkan bahwa jawaban sangat tidak setuju sebanyak $0(0,0 \%)$, jawaban tidak setuju sebanyak 62 (20,67\%), jawaban setuju sebanyak 118 (39,33\%), dan jawaban sangat setuju sebanyak 120 (40,00\%). Nilai rata-rata untuk item pernyataan kepemimpinan adalah 3,19. Hal ini menggambarkan bahwa sebagian besar karyawan menjalin hubungan komunikasi yang baik antar karyawan. Dari data diatas nilai rata-rata jawaban yang terendah adalah 3,14 dengan indikator integritas, hal ini 
Jurnal Profitability Fakultas Ekonomi Dan Bisnis

Volume 1 No 2 Tahun 2017

disebabkan karena masih ada beberapa karyawan yang belum bisa menaati peraturan yang diterapkan oleh perusahaan apabila tidak diawasi oleh pimpinan perusahaan. Dalam penelitian ini rata-rata jawaban tertinggi adalah 3,46 dengan indikator perencanaan, hal ini disebabkan karena perencanaan yang baik akan menjadikan perusahan memiliki tujuan yang jelas dan dapat mencapai visi dan misi perusahaan dengan baik.

\section{Variabel Mutu Pelayanan (Y)}

Variabel mutu pelayanandiukur menggunakan kuesioner yang terdiri dari 6 item pernyataan dengan indikator kualitas produk, harga, service quality, faktor emosional, kemudahan dan ketepatan. Berdasarkan hasil olah data penjabaran responden atas item yang digunakan untuk mengukur variabel mutu pelayanan, dapat ditunjukkan pada tabel 5.5 dan tabel 5.6 berikut ini:

Tabel 5.4 Distribusi Variabel Mutu Pelayanan

\begin{tabular}{|c|c|c|c|c|c|}
\hline No & Pernyataan & SS & $\mathbf{S}$ & TS & STS \\
\hline & Kualitas Produk & & & & \\
\hline 1 & $\begin{array}{l}\text { Kualitas produk sangat penting untuk } \\
\text { perusahaan. }\end{array}$ & 35 & 50 & 15 & - \\
\hline 2 & Keamanan barang konsumen terjamin & 48 & 34 & 18 & - \\
\hline \multirow[t]{2}{*}{3} & Barang tidak lecet sesuai sebelum digadaikan & 54 & 38 & 8 & - \\
\hline & Harga & & & & \\
\hline 4 & $\begin{array}{l}\text { Harga yang diberikan perusahaan sesuai } \\
\text { dengan kualitas produk. }\end{array}$ & 51 & 39 & 10 & - \\
\hline 5 & Biaya administrasi terjangkau & 62 & 29 & 9 & - \\
\hline \multirow[t]{2}{*}{6} & $\begin{array}{l}\text { Memberikan ganti rugi kepada konsumen } \\
\text { apabila barang tidak sesuai }\end{array}$ & 39 & 45 & 16 & - \\
\hline & Service Quality & & & & \\
\hline 7 & $\begin{array}{l}\text { Cepat tanggap dalam memberikan pelayanan } \\
\text { kepada konsumen. }\end{array}$ & 42 & 39 & 19 & - \\
\hline 8 & Prosedur layanan tidak berbelit-belit & 49 & 41 & 10 & - \\
\hline \multirow[t]{2}{*}{9} & Kesungguhan dalam memberikan layanan & 47 & 44 & 9 & - \\
\hline & Faktor Emosional & & & & \\
\hline 10 & Memberikan rasa senang dalam diri konsumen. & 63 & 31 & 6 & - \\
\hline 11 & $\begin{array}{l}\text { Konsumen merasa aman menitipkan } \\
\text { barangnya pada perusahaan }\end{array}$ & 34 & 51 & 15 & - \\
\hline \multirow[t]{2}{*}{12} & $\begin{array}{l}\text { Keamanan dan kenyamanan konsumen } \\
\text { selama pelayanan selalu terjaga dengan baik }\end{array}$ & 40 & 44 & 16 & - \\
\hline & Kemudahan & & & & \\
\hline
\end{tabular}


Jurnal Profitability Fakultas Ekonomi Dan Bisnis

Volume 1 No 2 Tahun 2017

\begin{tabular}{|c|c|c|c|c|c|}
\hline 13 & $\begin{array}{l}\text { Lebih mudah mendapatkan jasa di perusahan } \\
\text { yang di tempati. }\end{array}$ & 52 & 41 & 7 & - \\
\hline 14 & Memberikan pelayanan yang tepat dan cepat & 45 & 46 & 9 & - \\
\hline \multirow[t]{2}{*}{15} & $\begin{array}{l}\text { Waktu pengurusan pendaftaran dan } \\
\text { administrasi selalumemperhatikan kecepatan } \\
\text { pelayanan dan dilakukan denganbaik }\end{array}$ & 60 & 37 & 3 & - \\
\hline & Ketepatan & & & & \\
\hline 16 & $\begin{array}{l}\text { Ketepatan dalam pelaksanaan kegiatan } \\
\text { pelayanan untuk tujuan bersama dan } \\
\text { kenyamanan konsumen }\end{array}$ & 33 & 50 & 17 & - \\
\hline 17 & Konsistensi kualitas layanan yang diberikan. & 40 & 46 & 14 & - \\
\hline 18 & $\begin{array}{l}\text { Tepat waktu dalam pengambilan barang } \\
\text { konsumen }\end{array}$ & 48 & 46 & 6 & - \\
\hline
\end{tabular}

Sumber : Data diolah dari kuesioner, 2017

Berdasarkan tabel 5.5 diatas dapat dijelaskan bahwa deskipsi variabel mutu pelayanan dari masing-masing item pernyataan. Untuk item pernyataan tentang kualitas produk, harga, service quality, faktor emosional, kemudahan, dan ketepatan menunjukkan bahwa dari 100 responden didapatkan paling banyak yang menjawab sangat setuju (SS) ada pada indikator emosional yaitu 63 responden. Sedangkan paling sedikit ada pada indikator ketepatan yaitu 33 responden. Untuk jawaban setuju diperoleh paling banyak yang menjawab setuju (S) terdapat pada indikator faktor emosionalyaitu 51 responden sedangkan paling sedikit terdapat pada indikator harga yaitu 29 responden.

Pada jawaban tidak setuju diperoleh paling banyak yang menjawab tidak setuju (TS) terdapat pada indikator sevice quality yaitu 19 responden sedangkan paling sedikit ada pada indikator kemudahan yaitu 3 responden. Pada jawaban sangat tidak setuju (STS) semua indikator tidak terdapat satupun responden yang menjawab sangat tidak setuju.

Tabel 5.6 Persentase Distribusi Variabel Mutu Pelayanan

\begin{tabular}{|c|c|c|c|c|c|c|c|c|c|c|c|}
\hline \multirow[t]{3}{*}{ Indikator } & \multicolumn{8}{|c|}{ Alternatif Jawaban Responden } & \multirow{2}{*}{\multicolumn{2}{|c|}{ Jumlah }} & \multirow{3}{*}{$\begin{array}{c}\text { Mean } \\
\text { item }\end{array}$} \\
\hline & \multicolumn{2}{|c|}{ STS } & \multicolumn{2}{|c|}{ TS } & \multicolumn{2}{|c|}{ S } & \multicolumn{2}{|c|}{ SS } & & & \\
\hline & $\mathrm{F}$ & $\%$ & $f$ & $\%$ & $f$ & $\%$ & $f$ & $\%$ & $\mathrm{~F}$ & $\%$ & \\
\hline $\begin{array}{l}\text { Kualitas } \\
\text { Produk }\end{array}$ & 0 & 0 & 41 & 13,67 & 122 & 40,67 & 137 & 45,67 & 300 & 100,0 & 3,32 \\
\hline Harga & 0 & 0 & 35 & 11,67 & 113 & 37,67 & 152 & 50,67 & 300 & 100,0 & 3,39 \\
\hline Service & 0 & 0 & 38 & 12,67 & 124 & 41,33 & 138 & 46,00 & 300 & 100,0 & 3,33 \\
\hline
\end{tabular}


Jurnal Profitability Fakultas Ekonomi Dan Bisnis

Volume 1 No 2 Tahun 2017

\begin{tabular}{|c|c|c|c|c|c|c|c|c|c|c|c|}
\hline Quality & & & & & & & & & & & \\
\hline $\begin{array}{c}\text { Faktor } \\
\text { Emosional }\end{array}$ & 0 & 0 & 37 & 12,33 & 126 & 42,00 & 137 & 45,67 & 300 & 100,0 & 3,33 \\
\hline Kemudahan & 0 & 0 & 19 & 6,33 & 124 & 41,33 & 157 & 52,33 & 300 & 100,0 & 3,46 \\
\hline Ketepatan & 0 & 0 & 37 & 12,33 & 142 & 47,33 & 121 & 40,33 & 300 & 100,0 & 3,28 \\
\hline
\end{tabular}

Sumber : Data diolah dari kuesioner

Berdasarkan tabel 5.6 diatas dapat dijelaskan bahwa deskipsi variabel mutu pelayanan dari masing-masing item pernyataan. Untuk item pernyataan tentang kualitas produk menunjukkan bahwa dari 100 responden didapatkan jawaban sangat tidak setuju sebanyak $0(0,0 \%)$, jawaban tidak setuju sebanyak 41 (13,67\%), jawaban setuju sebanyak 122 (40,67\%), dan jawaban sangat setuju sebanyak 137 (45,67\%). Nilai rata untuk item pernyataan kualitas produk adalah 3,32. Hal ini menggambarkan bahwa sebagian besar karyawan mengatakan kualitas produk sangat penting untuk perusahaan karena menjadi prioritas pertama dalam mengukur harga barang.

Indikator kedua yang diukur adalah harga menunjukkan bahwa jawaban sangat tidak setuju sebanyak $0(0,0 \%)$, jawaban tidak setuju sebanyak 35 (11,67\%), jawaban setuju sebanyak 113 (37,67\%), dan jawaban sangat setuju sebanyak 152 (50,67\%). Nilai rata-rata untuk item pernyataan harga adalah 3,39. Hal ini menggambarkan bahwa pemberian harga yang diberikan perusahaan sesuai dengan kualitas produk. Indikator ketiga yang diukur adalah service quality menunjukkan bahwa jawaban sangat tidak setuju sebanyak $0(0,0 \%)$, jawaban tidak setuju sebanyak 38 (12,67\%), jawaban setuju sebanyak 124 $(41,33 \%)$, dan jawaban sangat setuju sebanyak 138 (46,00\%). Nilai rata-rata untuk item pernyataan service quality adalah 3,33. Hal ini menggambarkan bahwa cepat tanggap seorang karyawan penting dalam memberikan pelayanan kepada konsumen.

Indikator keempat yang diukur adalah faktor emosional menunjukkan bahwa jawaban sangat tidak setuju sebanyak $0 \quad(0,0 \%)$, jawaban tidak setuju sebanyak 37 (12,33\%), jawaban setuju sebanyak 126 (42,00\%), dan jawaban sangat setuju sebanyak 137 (45,67\%). Nilai rata-rata untuk item pernyataan faktor emosional adalah 3,33. Hal ini menggambarkan bahwa karyawan harus memberikan rasa senang kepada konsumen yang menerima jasa. Indikator kelima yang diukur adalah kemudahan menunjukkan bahwa jawaban sangat 
Jurnal Profitability Fakultas Ekonomi Dan Bisnis

Volume 1 No 2 Tahun 2017

tidak setuju sebanyak 0 (0,0\%), jawaban tidak setuju sebanyak 19 (6,33\%), jawaban setuju sebanyak 124 (41,33\%), dan jawaban sangat setuju sebanyak 157 (52,33\%). Nilai rata-rata untuk item pernyataan faktor emosional adalah 3,46. Hal ini menggambarkan bahwa karyawan memberikan kemudahan untuk mendapatkan jasa di perusahan yang tempati.

Indikator keenam yang diukur adalah ketepatan menunjukkan bahwa jawaban sangat tidak setuju sebanyak $0(0,0 \%)$, jawaban tidak setuju sebanyak 37 (12,33\%), jawaban setuju sebanyak 142 (47,33\%), dan jawaban sangat setuju sebanyak 121 (40,33\%). Nilai rata-rata untuk item pernyataan ketepatan adalah 3,28 . Hal ini menggambarkan bahwa karyawan memberikan pelayanan yang tepat untuk mendapatkan jasa di perusahan yang tempati.

\section{Hasil Uji Validitas dan Uji Realibilitas Data}

\section{1) Uji Validitas}

Validitas berasal dari kata validity yang mempunyai arti sejauh mana ketepatan dan kecermatan suatu instrumen pengukur dalam melakukan fungsi ukurnya. Validitas bertujuan mengkaji kesahihan alat ukur atau soal dalam menilai apa yang seharusnya diukur atau mengkaji ketepatan instrumen sebagai alat ukur. Dari data yang dilampirkan output nilai korelasi antara skor item dengan skor total. Nilai ini kemudian kita bandingkan dengan nilai $r$ tabel. Nilai $r$ tabel dengan signifikan 0,05 dengan $N=100$ maka diperoleh $r$ tabel 0,1654 . Dan Instrumen dikatakan valid apabila nilai $r$ tabel $<r$ hitung.

\begin{tabular}{|c|c|c|c|}
\hline \multirow{3}{*}{ Tabel 5.7 Hasil Uji Validitas Variabel Total Quality Management } \\
\hline & $\begin{array}{c}\text { Corrected } \\
\text { Item-Total } \\
\text { Correlation }\end{array}$ & $\begin{array}{c}\text { Cronbach's } \\
\text { Alpha }\end{array}$ & Keterangan \\
\hline Pernyataan 1 &, 531 &, 733 & Valid \\
\hline Pernyataan 2 &, 259 &, 749 & Valid \\
\hline Pernyataan 3 &, 285 &, 747 & Valid \\
\hline Pernyataan 4 &, 326 &, 744 & Valid \\
\hline Pernyataan 5 &, 275 &, 747 & Valid \\
\hline Pernyataan 6 &, 194 &, 761 & Valid \\
\hline Pernyataan 7 &, 243 &, 749 & Valid \\
\hline
\end{tabular}


Jurnal Profitability Fakultas Ekonomi Dan Bisnis

Volume 1 No 2 Tahun 2017

\begin{tabular}{|l|l|l|l|}
\hline Pernyataan 8 &, 236 &, 750 & Valid \\
\hline Pernyataan 9 &, 343 &, 743 & Valid \\
\hline Pernyataan 10 &, 196 &, 754 & Valid \\
\hline Pernyataan 11 &, 375 &, 742 & Valid \\
\hline Pernyataan 12 &, 345 &, 742 & Valid \\
\hline Pernyataan 13 &, 424 &, 738 & Valid \\
\hline Pernyataan 14 &, 323 &, 744 & Valid \\
\hline Pernyataan 15 &, 314 &, 745 & Valid \\
\hline Pernyataan 16 &, 230 &, 750 & Valid \\
\hline Pernyataan 17 &, 514 &, 734 & Valid \\
\hline Pernyataan 18 &, 269 &, 748 & Valid \\
\hline Pernyataan 19 &, 371 &, 741 & Valid \\
\hline Pernyataan 20 &, 305 &, 745 & Valid \\
\hline Pernyataan 21 &, 188 &, 752 & Valid \\
\hline Pernyataan 22 &, 168 &, 761 & Valid \\
\hline Pernyataan 23 &, 269 &, 748 & Valid \\
\hline Pernyataan 24 &, 412 &, 739 & Valid \\
\hline
\end{tabular}

Dari uji validitas pada tebel 5.5 di atas menunjukkan bahwa semua item pernyataan pada variabel Total Quality Management adalah valid.

\begin{tabular}{|c|c|c|c|}
\hline \multicolumn{5}{|c|}{ Tabel 5.8 Hasil Uji Validitas Variabel Mutu Pelayanan } \\
\hline & $\begin{array}{c}\text { Corrected Item- } \\
\text { Total Correlation }\end{array}$ & $\begin{array}{c}\text { Cronbach's } \\
\text { Alpha }\end{array}$ & Keterangan \\
\hline Pernyataan 1 &, 420 &, 893 & Valid \\
\hline Pernyataan 2 &, 503 &, 890 & Valid \\
\hline Pernyataan 3 &, 469 &, 891 & Valid \\
\hline Pernyataan 4 &, 505 &, 890 & Valid \\
\hline Pernyataan 5 &, 663 &, 885 & Valid \\
\hline Pernyataan 6 &, 470 &, 891 & Valid \\
\hline Pernyataan 7 &, 606 &, 887 & Valid \\
\hline Pernyataan 8 &, 654 &, 885 & Valid \\
\hline Pernyataan 9 &, 612 &, 887 & Valid \\
\hline Pernyataan 10 &, 646 &, 886 & Valid \\
\hline Pernyataan 11 &, 465 &, 891 & Valid \\
\hline
\end{tabular}


Jurnal Profitability Fakultas Ekonomi Dan Bisnis

Volume 1 No 2 Tahun 2017

\begin{tabular}{|c|c|c|c|}
\hline Pernyataan 12 &, 533 &, 889 & Valid \\
\hline Pernyataan 13 &, 512 &, 890 & Valid \\
\hline Pernyataan 14 &, 655 &, 885 & Valid \\
\hline Pernyataan 15 &, 555 &, 889 & Valid \\
\hline Pernyataan 16 &, 496 &, 890 & Valid \\
\hline Pernyataan 17 &, 394 &, 894 & Valid \\
\hline Pernyataan 18 &, 517 &, 890 & Valid \\
\hline
\end{tabular}

Dari uji validitas pada tebel 5.6 di atas menunjukkan bahwa semua item pernyataan pada variabel Mutu Pelayanan adalah valid.

\section{2) Uji Reliabilitas}

Reliabilitasadalah suatu tingkatan yang mengukur konsistensi hasil jika dilakukan pengukuran berulang pada suatu karakteristik. Pengujian reliabilitas dapat dihitung dengan menggunakan formula Cronbach's Alpha yang di uji menggunakan SPSS 18. Koefisien keandalan dianalisis dengan menggunakan rumusAlphaCronbach atau Koefisien Alfa. Semakin tinggi koefisien keandalan berarti semakin tinggi keandalan suatu instrumen. Besar koefisien keandalan berkisar antara 0 sampai 1,00. Bila koefisien reliabilitas semakin tinggi mendekati angka 1,00 maka hal ini berarti pengukuran semakin reliabel. Sehingga instrument dikatakan reliabel jika nilai Alpha Cronbachs > 0,6.

\begin{tabular}{|r|c|c|}
\hline \multicolumn{4}{|c|}{ Tabel 5.9 Uji ReliabilitasVariabel Total Quality Management } \\
\hline $\begin{array}{c}\text { Cronbach } \\
\text { 's Alpha }\end{array}$ & $\begin{array}{c}\text { Cronbach's Alpha Based on } \\
\text { Standardized Items }\end{array}$ & N of Items \\
\hline, 754 &, 766 & \\
\hline
\end{tabular}

\begin{tabular}{|r|c|c|}
\hline \multicolumn{3}{|c|}{ Tabel 5.10 Uji Reliabilitas Variabel Mutu Pelayanan } \\
\hline $\begin{array}{r}\text { Cronbac } \\
\text { h's Alpha }\end{array}$ & $\begin{array}{c}\text { Cronbach's Alpha Based on } \\
\text { Standardized Items }\end{array}$ & N of Items \\
\hline, 895 &, 896 & 18 \\
\hline
\end{tabular}

Berdasarkan tabel 5.9 dan tabel 5.10 menunjukkan bahwa variabel Total Quality Management dengan Cronbach's Alpha 0,754 dan variabel Mutu Pelayanan dengan Cronbach's Alpha 0,895. Dengan demikian kedua variabel penelitian reliabel. 
Jurnal Profitability Fakultas Ekonomi Dan Bisnis

Volume 1 No 2 Tahun 2017

\section{Uji Asumsi Klasik}

Sebelum dilakukan pengujian hipotesis menggunakan regresi linier sederhana, ada beberapa uji asumsi klasik yang harus dipenuhi agar kesimpulan dari regresi tersebut tidak bias, yaitu uji normalitas, uji multikolinieritas, uji Autokorelasi, uji heteroskodesitas dan uji linieritas.

1) Uji Normalitas

\begin{tabular}{|l|c|c|c|c|c|c|}
\hline \multicolumn{7}{|c|}{ Tabel 5.11Tests of Normality } \\
\hline & \multicolumn{2}{|c|}{ Kolmogorov-Smirnov ${ }^{\mathrm{a}}$} & \multicolumn{3}{|c|}{ Shapiro-Wilk } \\
\cline { 2 - 7 } & $\begin{array}{c}\text { Stati } \\
\text { stic }\end{array}$ & $\mathrm{df}$ & Sig. & $\begin{array}{c}\text { Stati } \\
\text { stic }\end{array}$ & df & Sig. \\
\hline Unstandardized &, 100 & 1 &, 106 &, 942 & 1 &, 000 \\
Residual & & 0 & & & 0 & \\
& & 0 & & & 0 & \\
\hline
\end{tabular}

Berdasarkan tabel di atas menunjukkan bahwa nilai $p=0,106>0,05(\alpha)$. Hal ini berarti data yang diperoleh dari sampel penelitian berasal dari populasi yang berdistribusi normal.

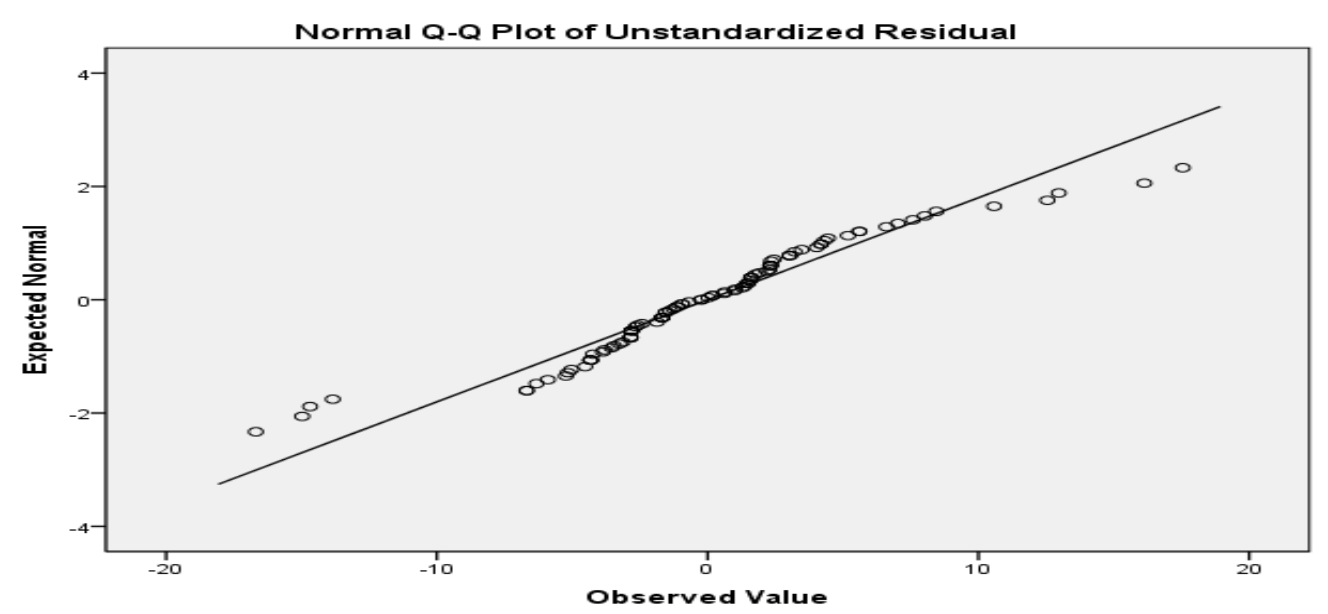


Jurnal Profitability Fakultas Ekonomi Dan Bisnis

Volume 1 No 2 Tahun 2017

2) Uji Linieritas

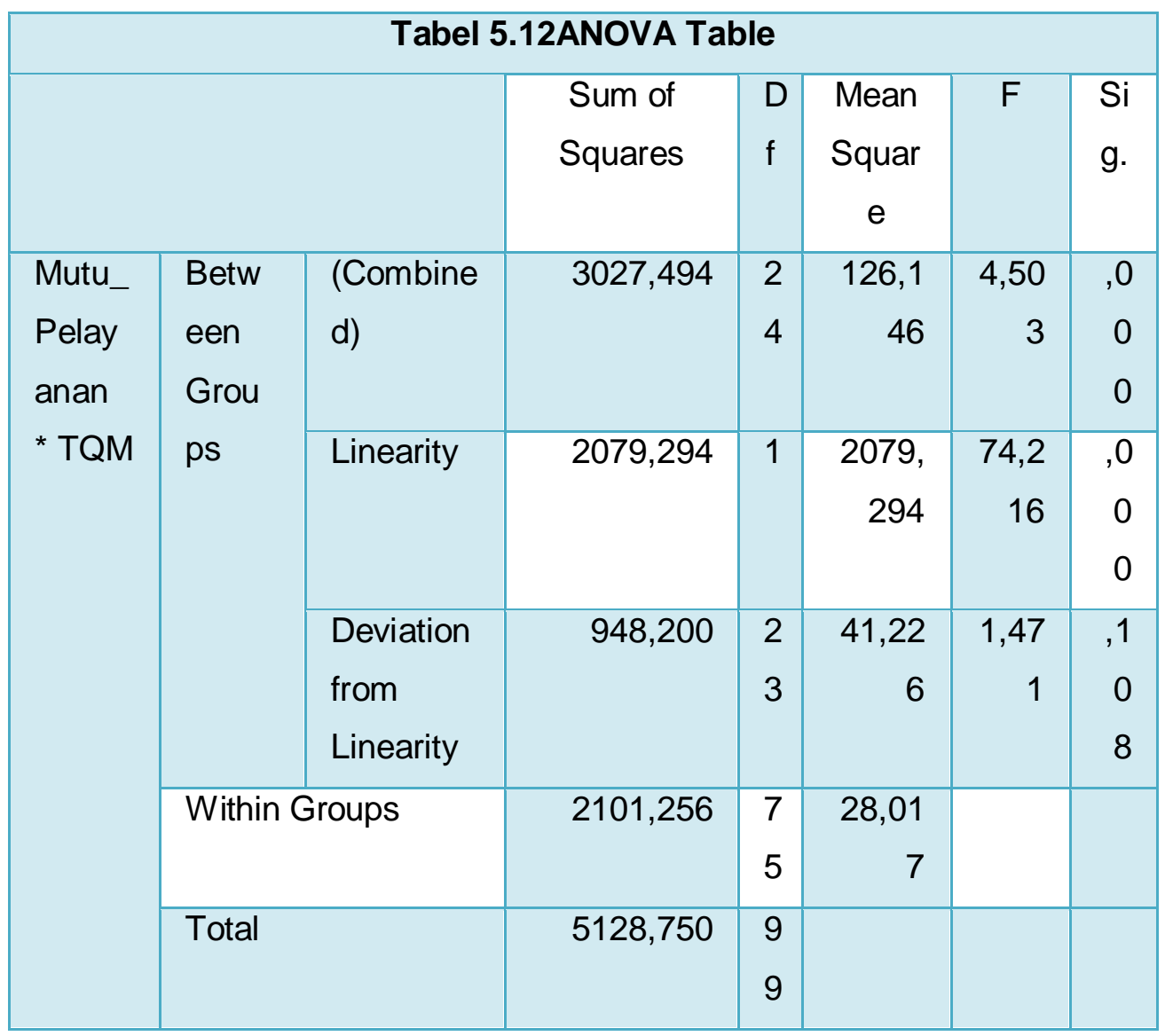

Berdasarkan tabel di atas menunjukkan bahwa nilai $p=0,108>0,05(\alpha)$. Hal ini berarti ada hubungan linear antara Total Quality Management dengan Mutu Pelayanan. Karena uji linearitas terpenuhi maka dalam analisis digunakan regresi sederhana. Untuk mengetahui ada tidaknya pengaruh variabel bebas dengan variabel terikat secara parsial diperlukan uji hipotesis atau uji parsial (uji t). Dalam pengujian hipotesis peneliti menggunakan alat bantu SPSS for windows versi 18.00 dengan ketentuan jika Ha ditolak apabila $t_{\text {hitung }}<t_{\text {tabel }}$ atau probilitas nilai $t>$ 0,05 . Sebaliknya jika Ha diterima apabila $t_{\text {hitung }}>t_{\text {tabel }}$ atau probilitas nilai $t<0,05$. Berdasarkan hasil olah data diketahui $t_{\text {tabe }}$ dalam penelitian ini derajat kebebasan $\mathrm{df}=100-1-1$ dengan signifikan $5 \%$ adalah 0,05 . Sedangkan $t_{\text {hitung }}$ adalah sebagai berikut: 
Jurnal Profitability Fakultas Ekonomi Dan Bisnis

Volume 1 No 2 Tahun 2017

Tabel 5.13 Distribusi Variabel Mutu Pelayanan

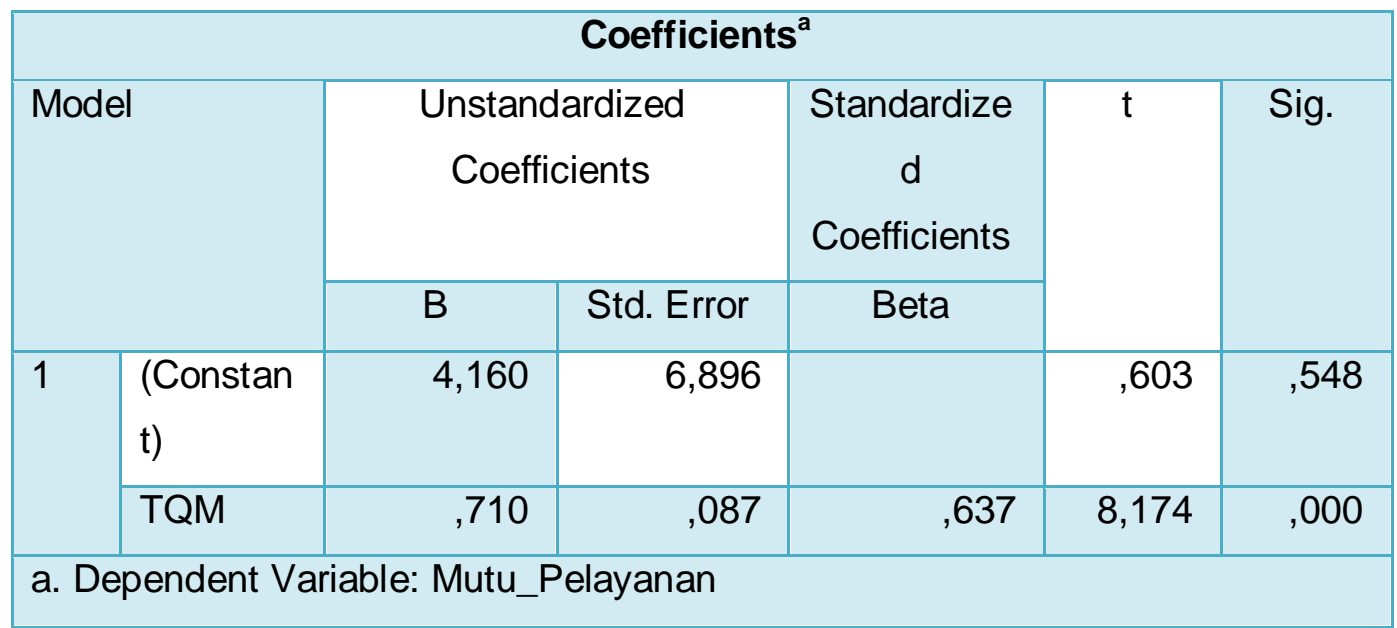

Berdasarkan hasil analisis regresi linear sederhana pada tabel diatas diperoleh koefisien untuk untuk variabel bebas $X=0,710$ dan konstanta sebasar 4,160 sehingga model persamaan regresi yang diperoleh :

$$
\mathrm{Y}=4,160+0,710 \mathrm{X}
$$

Dimana:

$\mathrm{Y}=$ Variabel mutu pelayanan

$\mathrm{X}=$ Variabel TQM (Total Quality Management)

$\mathrm{a}=$ Nilai Konstanta $(\mathrm{Y})$ sebesar 4,160

$\mathrm{b}=$ Koefisien regresi X (Total Quality Management)

Dari perhitungan regresi linear sederhana didapat nilai coefficients $(b)=$ 0,710. Hal ini berarti Total Quality Managementberpengaruh positif terhadap mutu pelayanan. Nilai signifikansi diperoleh lebih kecil $(<)$ dari $0,05(0,000<$ 0,05)sehingga $\mathrm{H}_{1}$ diterima yaitu Total Quality Management berpengaruh positif terhadap Mutu Pelayanan pada PT. Pegadaian Cabang Soppeng.

Tabel 5.14 Koefisisen Determinasi

\begin{tabular}{|c|c|c|r|r|}
\hline Model & $\mathbf{R}$ & $\begin{array}{c}\mathbf{R} \\
\text { Square }\end{array}$ & $\begin{array}{c}\text { Adjusted R } \\
\text { Square }\end{array}$ & \multicolumn{2}{|c|}{$\begin{array}{c}\text { Std. Error of the } \\
\text { Estimate }\end{array}$} \\
\hline $\mathbf{1}$ & $0,637^{\mathrm{a}}$ & 0,405 & 0,399 & 5,578 \\
\hline
\end{tabular}

Tabel 5.6 menunjukkan nilai $\mathrm{R}$ square 0,405 yang memberikan informasi bahwa model mempunyai daya ramal $40,5 \%$ variasi $Y$ (Mutu Pelayanan) dapat dijelaskan oleh model. Nilai R kuadrat terkoreksi 0,399 yang menunjukkan bahwa Total Quality Management (TQM) dapat menjelaskan sekitar 39,9\% variasi Y (Mutu Pelayanan). 
Jurnal Profitability Fakultas Ekonomi Dan Bisnis

Volume 1 No 2 Tahun 2017

\section{Pembahasan}

Hasil penelitian menunjukkan bahwa sebagian besar responden PT. Pegadaian Cabang Soppeng mempunyai Total Quality Management yang tinggi. Hal ini dibuktikan oleh karyawan disiplin dalam menjalankan hal-hal yang dianggap baik oleh perusahaan dan menghindarkan diri dari tindakan-tindakan yang dianggap buruk, taat pada peraturan-peraturan baikdiawasi maupun tidak diawasi, percaya terhadap hasil kerja karyawan lain, keahlian personal harus sesuai dengan pekerjaan masing-masing, kerjasama tim dalam organisasi sangat penting dalam menyelesaikan permasalahan, sangat setuju untuk pemberian penghargaan bagi karyawan yang berprestasi dan menjalin hubungan komunikasi yang baik antar karyawan. Tinggi total quality management ini ditunjukkan dari sikap positif karyawan terhadap PT. Pegadaian Cabang Soppeng. Para karyawan merasa total quality management sangat diperlukan dalam meningkatkan mutu pelayanan. Berdasarkan hasil analisis regresi linear sederhana diperoleh nilai $t_{\text {hitung }}$ adalah 8,174 sedangkan nilai $t_{\text {tabel }}$ sebesar 1,98397. Hal ini membuktikan bahwa nilai $t_{\text {hitung }}$ lebih besar dari pada $t_{\text {tabel. }}$. Dengan demikian Ha diterima. Interpretasi menunjukkan bahwa penerapan total quality management berpengaruh dalam hal meningkatkan mutu pelayanan terhadap kinerja perusahaan pada PT. Pegadaian Cabang Soppeng.

Total Quality Management merupakan suatu sistem yang dapat dikembangkan menjadi pendekatan dalam usaha untuk memaksimumkan daya saing organisasi melalui perbaikan terus menerus atas produksi, jasa, tenaga kerja, proses. Menurut Nasution(2010), Total Quality Management merupakan suatu sistem manajemen yang difokuskan pada seluruh orang atau tenaga kerja, mempunyai bagian untukmeningkatkan kepuasan pada pelanggan dengan memberikan kualitas yang sesuaidengan standar perusahaan, dengan biaya pencapaian nilai lebih rendah dari nilaisuatu produk atau jasa. Dalam konsep ini diperlukan suatu komitmen dari setiapanggota dalam organisasi atau perusahaan. Berdasarkan hasil penelitian Total Quality Managementberpengaruh positif dalam meningkatkan mutu pelayanan pada nasabah. Karena dengan adanya Total Quality Managementyang tinggi akan memperbaiki kinerjadalam mengelola perusahaan agar dapat meningkatkan penghasilan perusahaan. 


\section{PENUTUP}

\section{Simpulan}

Berdasarkan hasil analisis dan pembahasan yang telah dikemukakan sebelumnya, maka dapat ditarik kesimpulan bahwa dari hasil analisis regresi linear sederhana diperoleh nilai $t_{\text {hitung }}$ adalah 8,174 sedangkan nilai $t_{\text {tabel }}$ sebesar 1,98397. Hal ini membuktikan bahwa nilai $t_{\text {hitung }}$ lebih besar dari pada $t_{\text {tabel- }}$ Dengan demikian Ha diterima. Interpretasi menunjukkan bahwa Penerapan Total QualityManagement berpengaruh positif dalam hal meningkatkan mutu pelayanan nasabah pada PT. Pegadaian Cabang Soppeng.Karena dengan adanya Total Quality Managementyang tinggi akan memperbaiki kinerjadalam mengelola perusahaan agar dapat meningkatkan penghasilanperusahaan.

\section{Saran}

Dari hasil kesimpulan yang telah dikemukakan, maka adapun saran yang dapat diberikan sehubungan dengan kesimpulan tersebut adalah sebagai berikut:

1. Diharapkan karyawan untuk meningkatkan Total Quality Manajemen di PT. Pegadaian Cabang Soppeng demi meningkatkan mutu pelayanan.

2. Diharapkan pula karyawan agar meningkatkan integritas kesadaran karyawan dalam hal kehadirannya demi meningkatkan mutu pelayanan sehingga dapat menghasilkan kinerja yang baik pula.

3. Untuk peneliti selanjutnya diharapkan menambah komponen dalam penelitian selanjutnya seperti gaya kepemimpinan terhadap mutu pelayanan. 
Jurnal Profitability Fakultas Ekonomi Dan Bisnis

Volume 1 No 2 Tahun 2017

\section{DAFTAR PUSTAKA}

Amrine, Harold T, 2004, Pengantar Manajemen, Second Edisi Kedua, Cetakan Ketujuh, Jakarta.

Frianto, Pandia, 2005, Lembaga Keuangan, Edsi Kedua, Cetakan Kedelapan, Penerbit FE, UGM, Yogyakarta.

Hadi, S. 2015. Metodologi Riset. Yogyakarta: Pustaka Pelajar.

Harding, H.A, 2009, Production Management, Second Edition, London, McDonald and Evans Limited.

Husnan Suad, Manajemen Keuangan: Teori dan Penerapan Buku 1, Edisi 4, BPFE Yogyakarta, 2008.

James, A.F, 2005, Manajemen Personalia, Yayasan Agro Ekonomika, Yogyakarta.

Marting Kenneth, 2007, Produk Manajemen Mutu, New York, John McGraw-Hill Book Company.

Martono, 2003, Bank Lembaga Keuangan Lainnya, Edisi Kelima, Cetakan Ketiga, Arisco, Yogyakarta.

Mayes H. Robert, 2004, Manajemen Produksi, BPFE, UGM, Yogyakta.

Mubyarto, 2008, Pengantar Manajemen, Bagian Penerbit Fakultas Ekonomi Universitas Gajah Mada, Yogyakarta.

Nasution, M. N. 2010. Manajemen Mutu Terpadu: Total Quality Management. Jakarta: Ghalia Indonesia.

Poerwadarminta, 2006, Tata Laksana Kantor (Manajemen Per Kantoran), Mandar Maju, Bandung.

Rahman, Abdul, 2006, Manajemen Per Kantoran Modern, Cetakan ke-1 Binarupa Aksara, Jakarta.

Richard, 2010, Cost Accounting, Fourth Edition, Private-Hall New York.

Tiro, M. A. 2013. Analisis Korelasi dan Regresi. Makassar: Andira Publisher

Tjiptono, F., \& Diana, A. 2003. Total Quality Management. Yogyakarta: Andi Offset.

Umar, H. 2011. Metode Penelitian untuk Skripsi dan Tesis Bisnis. Jakarta: Rajawali Pers.

Wibowo. 2008. Manajemen Kinerja. Jakarta: Rajawali Pers.

Yunus, M, 2005, Administrasi Modern, Cetakan ke-1, CV. Titik Terang, Jakarta. 